\title{
ULUSAL DEVLET OLMA YOLUNDA TÜRKIYE
}

\section{Dr. Bülent KARA*}

\section{ÖZET}

Osmanlı Beyliği, başarılı yöneticileri ve bu yöneticilerin gerçekleştirdioği fetihler sayesinde imparatorluğga dönüşmüștür. Bünyesinde çessitli ırklan, dinleri, mezhepleri ve tabi ki dilleri barındıran bu imparatorluk aynı zamanda bu gruplara oldukça hoş görülü divranmışur. Fransız lhtilali’nin ortaya çıkardığı "milliyeıçilik" akımı, her imparatorluk gibi Osmanlı İmparatorluğu'nu da sarsmışur. Çünkii, imparatorluğun bünyesindeki farklı gruplar da milliyetçilik akınının cazibesine kapılmışlardır. Bütün bu gelişmelere rağgmen imparatorluğun asıl kưucu kesimi olan Türkler, imparatorluğun devamı için bu akıma sırtlarını dơnmüşlerdi. İmparatorluk artık karşı koyulamayacak kadar gựclï darbclerle karşılaşmaya bașlanuștı. Bu darbeler şiddetlendikçe Türkler arasında da milliyetçilik fikri gelişmeye başlamıştı. İmparatorluktan arta kalan topraklarda Türkler, yeni bir devlet için mücadele bașlattı. Bu micadci”, tarihte "Kurtuluș Savaşı" olarak yerini aldı. Kanlı 'ii boğgşmadan sonra yeni bir devlet kuruldu. Bu devlel Türkiye'dir ve cumhuriyetin ilanından sonra da adı "Türkiye Cumhuriyeti"ne dönüșmüștür. Simdi bu devlette de diğer devletlerde olduğu gibi ulusal bir politika uygulanacaktı. Devlctin kurucusu olan Mustafa Kemal Atatiirk; yine biiyilk bir devlet adamı ve devrimci olarak dil ve tarih, din, cŏgitim ve daha pek çok alanda ulusallaşma yönünde yenilikler gerçekleștirdi. Onun bu çalışnalan asla ırkçı̆ı̆̆a yönelmedi. Çünkü 0 , herkesi vatandaş̣lı bağıyla henimsedi ve bu bağ benimseyen herkes için "Ne mutlu Tïrk'üm diyene." dedi.

\section{Osmanlı Imparatorluğg' nun Tebaa (Vatandaş) Yaklaşımı}

$\mathrm{M}$

illiyetçilik konusunda herhangi bir kaynağa başvurulduğunda, istisnasız olarak "Fransız İhtilali"nden söz, edildiği görüllmektedir. (Yine Fransız. İhtilali ve milliyetçilik hakkında söylenen son sözler bu eylemle, ulus devletterin ortaya çıtı̆ yönünde olmaktadır.) Elbette ki her ulusal devletin ortaya çıkışı farklı özcllikler gösterebilir. Ancak bu ulus devletlerden birisi olan ve belki de ulusal devlet olarak ortaya çıkış diğer devletlere göre bir hayli gecikmeli olan

"Atatüik Üniversitesi Ağrı Eğitim Fåkültesi Öğretim Görevlisi. 
'T'ürkiye'nin bu yoldaki mücadelesini öğrenmek. ̈̈zellikle üzcrinde yaşayan inšanlar için claha heyecanlı ve çekici olmaktadır. Dolayısıyla Türk devletinin ulusalcı yaklaşımını ve bu konudaki bazı aşamalarına değinmeyi bir sorumluluk olarak kabul ettik.

Acaba Tüirkiye'nin ulus devlet olması yolunda nasıl bir çaba sarf edildi?

Bu çalışnada ulus devlet olma çabaları anlatılırken Türkiye'de kalan ażnfıklarm durumlarıı da gömek mümkün olacaktır. Bu arada Osmanlı Imparalorluğu'nun yayılması ile sosyal yapıda oluşan gelişmeler, değişmeler kısaca ele almacak ve Jevralınan mirasın yeni Türk Devleti dönemindcki değişiıni gö̈sterilmeye çalışılacaktır.

1281'li yıllarda Söğüt civarnnda yaşayan küçük bir 'Türkmen grubu; Bilecik, Yarhisar, İnegöl kasabalarını da egemenliğinc katarak büyiime eğilimi göstermiş ve çevresinde "Osmanlılar" adıyla tånınmaya bașlamıștı.'

XVl. yüzyılın sonlarında artık küiçük bir Osmanlı Beyliği’nden söz. edilemez. Cünkü bu beyliğin smmrlar; Karadeniz ve Ege Denizi'nden Adriyatik ve Jyonya Denizine; Karpatlardan Akdeniz'e kadar genişlemiş, Asya ve Atrika'da ise şu ïlkcleri cgemenliği altına almışı: Küçük Asya, Kafkasłar. Suriyc, Mczopotamya. Arabistan, Mısır,Trablusgarp, Tunus ve Cezayir..2 Bu gelişmeler sonrasmda Beylik, bir imparalorluğa dön iş̧müş̧ü.

Bu kadár geniş alanı hakimiyeti altmda tulan Osmanl İmparatorluğu, egemenlik anlayışında da en az toprakları kadar genenş bir hoşgörüuyii ön planda tutmak zorundaych. Çünküi; imparatorlık Tüirkler bașta olmak üzcre; Bulgarlar, Suplar. Romanyalılar, Amavutlar, Yunanlılar, Ermeniler, İsrailliłer, Araplar, Suriycliler ve Keldaniler, Diirziler, Kürtler, Gürcüler, Çerkez.ler gibi toplulukları bünyesinde toplamıştı.

Osmanlı jmparatorluğu farklı köken ve dine mensup topluluklara egemen olmasina rağmen. onlana karşı adil divranmış ve bir baskı veya asimilasyon politikası uygulamarmş̧ır. Bu davramıs şekli, Türklerin tarihsel mirası olduğu gibi. Islamiyet'in de beklentisiydi.

Osmanlı Imparatorluğu'nun yayılmassm kolaylaştıran en önemli etkenlerden birisi: hiç şüphesiz ki yukarıda belirtilen özellikler çerçevesinde Osmanlinn fethettiği yerlerdeki köylüleri derebeylerin zulmünden kurtarıp, devlelin köylüsiui olarak kabul etmesi gerçeği de yalmakladır. Bu anlayışla yaklaşıldığı için fetih sonrasında köylülere herhangi bir baskı uygulanmıyor, onlara özgiillik tanmuyordu. ${ }^{3}$

\footnotetext{
' Sina Akşin, Türkiye Tarihi, II, Osmanh Devleti 1300-1600, Istanbul, 1989, s.21.

'A. Zeki P'olar, Osmanli İmparatorluğn'nun Çöküs Sebepleri, İstanbul, 1962, s.3.

'Erol Güngö, Tarihte Türkler, İstanbul, 1993, s. 191.
} 
Osmanlı İmparatorluğu'nun bu hoşgörüsünü: "....Htristiyanlar devlet memuru olmadiklan için, yüksek devlet memurlarl, kendi yerleri tehlikeye girmesin diye, kitle halinde Islamlığın kabul edilmesine karşydlar, seklinde açıklayanlara da rastlanmaktadır. Osmanlı İmparatorluğu yöneticilerinin bu hoşgörüsünün nedeni ne olursa olsun neticede egemenliği altındaki inșanlarm mutlu olduğu bilinmektedir. ${ }_{5}$ Bu mutluluk XVII. yǚyılda bozulmaya başladı. Çünkü başlangıçtaki veriliş amacindan sapan Kapitülasyonlar, Osmanlı İmparatorluğu'na yıkıcı ekonomik darbeler vurmaya başlamıştı.

Yine XVIT, ve XVIII. yüzyıllarda karşılaşılan bazı yenilgiler ve bu yenilgilerden sonra imzalanan anlaşmalar, Osmanlı İmparatorluğa için sonun başlangıcı kabul edilebilir. Öneğin 1699 tarilıli Karlofça Antlaşması ${ }^{6}$ ile İmparatorluk ilk kez toprak kaybetmeye başlamış ve 1774 tarihinde imzalanan Küçük Kaynarca Antlaşması ${ }^{7}$ ile de Ruslar, Osmanlı İmparatorluğu içindeki Ortodokslar için koruyucu olarak kabul edilmişti.

Osmanlı İmparatorluğu'nda uyum içerisinde yaşayan gruplar dış güçlerin müclahalesiyle yavaş yavaş uyumu bozma noktasına geldiler. Aslunda Osmanlı azınlıkları uyumu bozma durumuna getirildiler yaklaşımı daha doğru olacaktır. Çünkü; bu yenilgiler sonrasında özellikle Rusya, Osmanlı İmparatorluğu'nun iç işlerine müdahale edebilmek için Balkanlar'dan sonra yeni bir arạ arayışına koyuldu. Rusyán'nın bu konuda kullanacağı araç dá tábîi ki Ermeniler oldu. Osmanlı Imparatorluğu'nun iyice zayıflaması ve diğger devletlerin de işe karışmasıyla bu durum, "Ermeni Sorunu' "na dönüștui."

Osmanl İmparatorluğu'nun etkilendiği olumsuz koşullar elbette ki bununlá smırh değildi. Her geçen gün artarak devam edern toplumsal, ekonomik ve siyasal

4 "... Osmanlhlarn miisamahalan ister siyaset, ister halis insaniyet, isterse lakaydi neticesi ile mevdana gelmis olsun, su vakuva itiraz edilemez ki Osmanldar yeni zaman işinde millivetlerini tesis ederken dini hiirriyet undesini temel taş olmak iizere vazetmis ilk millettir; arast kesilmeyen Yaludi tezibatl ve engizisyona resmen muavenet mesuliveti lekesini tassyan astarlar esnasmda Hiristiyan ve Müsliumanlar, Osmanlalarm idaresi altunda ahenk ve vifak içinde yaşyorlardl...."Ismail Hakkı Uzunçarşılı, Osmanlı Tarilì, I, Ankara, 1988 , s.184-185.

5 "... Osmanlilarm müsamahalar ister siyaset, ister halis insanivet, isterse lakaydi neticesi ile meydana gelmis olsum, şu vakuya itiraz. edilemez ki Osmanlular yeni zamun içinde milliyetlerini lesvis ederken dini hiïriyet undesini temel tast olmak üzere vazetmis ilk millettir; arast kesilmeyen Yahudi tezibat ve engizisyona resmen muavenet mesuliyeti lekesini taşyan asirlar esnasunda Hiristiyan ve Mïslïnanlar. Osmanllarm idaresi alında ahenk ve vifak içinde yaşıyorlarch...."Ismail Hakkı Uzunçarşıllı, Osmanlı Tarihi, I, Ankara, 1988, s.184-185.

"İsmail Hakkı Uzunçarşııı, Osmanlı Tarihi, III/I, Ankara, 1983, s.589-595; İsmail Hami Danişmend, Izahlı Osmanlı Tarihi Kronolojisi, III, İstanbul, 1972, s.484-486.

7 İsmail Hakkı Uzunçarşılı, Osmanlı Tarihi, IV/ I, Ankara. 1982, s.422-425.

${ }^{8}$ Kongar, 21.Yüzyılda Türkiye, s. 54. 
yozlaşma; Batılılaron teknik alandaki ilertemeleri ve bunu üretimde kullanması, ayrıca siyasi alanda da Fransız İhtilali ile ortaya çıkan "Milliyctçilik", "Özgüirlük" düşünccleri imparatorluğun temelinde sarsmtılar oluşturmaya başladı. Ciünkü bu kavramlatrın ortalya çıkşıyla devletin temelini oluşturan hukuk sistemine yönelik sorgulamalar başlad.

Osmanlı İmparatorluğu’nda egomen hukuk sistemi İslam Hukuku olduğu için. ülkede var olan grupların hukukları da İslam Hukuku’nun özüne göre şekillenmekıeydi. Başka bir tanımla, hukuk kurallarının oluşumunda İslamiyet'in hosgörüisii oranında diğer dinlere ve mezheplere de en azından cemaatler bazında izin verilmiştir." Bu izin, aynı zamanda Osmanlı İmparatorluğu bünyesinde yaşayan larklı köken ve dinlere mensup grupların kimliklerini korumalarını săglamıştır.

\section{Osmanlı İmparatorluğgu'nda Demokratikleşme Süreci ve Ulusallaşıı}

Osmanlı sınırları içinde yaşayan gayrimüslim unsur|arın olumsuz. Lavirlarına rağmen Osmanlı yöneticileri onlara kâş̧ olumsuz bir tutum takınmadıkları gibi yeniden mutlu günlcre dönebilmck için bił tákım çabalar göstermişlerdir. Örneğin 1839 yılında ilan edilen Gülhane Hatt-1 Humayunu ile herkesin can, mal, 117, namus guivenliği teminal altına alımış ve ana haklar kabu] edilmiştir."

Osmanlı İmparatorluğu bu ferman jle tüm vatandaşlarını din, mezhep farkı gözetmeksizin bir tek "Osmanlr Tebaası" ideali ctrafında birleştirmek istiyordu." Osmanlı yönetiminin bu isteğine karşı çıkışlar vădı. Karşı çıkanların başında Rumlar geliyordu. Cünkü Rumlar sahip olduklar bazı ayrıcalıklar diğerleriyle paylaşmak istemiyordu. Rumların bu yaklaşımını kamılayan en güzel örnek ise hiç şüphesiz. ki Rum patriğinin daha ferman okunurken söylediği şu sözlerdir: "Inşallah bir daha bu keseden dişarl çımaz"."?

Osmanlı İmparatorluğu bu fermanın yaymlanmasiyla billikte adeta demokratikleşme sürecine girmişti. Ançak bundan sonraki gelişmeler de ele almelğguda bu demokratikleşme döneminin bir parçalanma sürecini de başattığ görülmektedir.

Osmanlı tarihinde 1. ve If. Meşrutiyet döneni olarak adlandırılan demokratikleşme sürecinde yine Osmanlı tarihi için oldukça büyük önem arz edeı

\footnotetext{
"Bülent Kară, Tabiiyetten Vatandaşığa Geçiş Sürecinde Tür-kiye'de Azınlıklar ( 1923 1950). (Basilmamis Dokıra Tezi), Erzurum, 2004, s. 11.

11 Başbakanhk Osnanlı Arşivi (BOA). Irade-i Mesail-i Mühimme 24; Mahmut Essat Bozkiul, Atatürk İhtilali, İstanbul, 1995, s.44-47.

"Hakan Alkan, 500 Yıllık Serüven, Belgelerle Türkiye Yahudileri. I, Ankara, 2000, s. 79.

${ }^{12}$ Enver Ziya Káral, Osmanlı Tarihi, V. Ankara, 1983, s. 187.
} 
iki siyasi oluşum ortaya çıkmıştır. Meşrutiyet yönetiminin ilanında etkili olan bu gruplar; Yeni Osmanlılar ve Jön Türklerdir.

Yeni Osmanlılar; Osmanlı İmparatorluğu'nda batılılaşma çalışmalarına tepki olarak ortaya çıkmış bir aydınlar grubudur. "Bürokrat" olarak tanımlanabilecek yazar, memur ve subaylardan oluşan bu grup, imparatorluğun merkezileşme ve batı eğitiminin bir sonucudur.

Bu aydınlar grubuna göre; sürekli toprak kaybının önüne geçebilmenin yolu ve Osmanlı İmparatorluğu'nun kalkınması "Meşveret" sayesinde gerçckleşecektir. "Meşveret" ile yönetim düzeltilecek tüm Osmanlılar -ırk ve din ayrımından uzaklaşarak- birbirine kenetlenecek ve devlete bağlılıkları artacaktır.

Yeni Osnánlılar ulusal duygulardan uzak durmuşlardır. Onların benimsedikleri temel kavram "din" olmuştur. Bunun içindir ki, batının ekonomik baskılarına karşı yerli "banka", "şirket", "tüccar", "fabrika" önerirken bunların başına "Müslüman" kelimesini eklemeği ihmal etmemişlerdir. Yeni Osmanlılar devletin kurtuluş çözümünü ózgür]ük ve eğitimde bulmuş ancak kısa bir süre sonra yanıldıklarını da anlamışlardır. ${ }^{13}$ Çünkü; 23 Aralık 1876 yılında Sultan II. Abdulhamit tarafından ilan edilen Meşrutiyet yönetimi, özgürlük veya "demokrasi" getirirken imparatorluğun dağılmasını önlemede bekleneni verememiştir.

Osmanlı tarihinde düşünce alanında varlıklarıyla önemli bir yer tután ikinci ayclınlar grubu ise Jön Türklerdir.

Jön Türkler, Yeni Osmanlılara göre bürokrasinin daha alt tábakalarından ve toplumsal köken olarak da daha alı sınıflardan oluşmuşlardır.

Jön 'Türkler, Yeni Osmanlılara göre batı eğitiminden daha çok etkilenmişlerdi ve akılcı düşünceye yatkınlıkları da daha fälaydı.

Jön Türkler, devleti kurtarmak için kolları sıvadığında ellerinde bu iş için anahtar görevi yapabilecek "Osmanlıcılık" ve "İslamcılık" gibi iki düşünce vardı. Fakat Jön Türklerin ve tabii ki onların siyasal örgütlenmesi olan Ittihat ve Terakki’nin bir üçüncü anahtar buldukları görülmektedir ki bu anahtar, "Türkçüilük" tür.

Tarihi seyir içerisinde "Osman]ıcılı" fikrinin özellikle gayrimüslim unsurları Osmanlı İmparatorluğu'na sadık birer tebaa olarak tutamadığı bilinmektedir. Bütün ümitlere ve gayretlere rağmen "Islamcılık" fikri de bekleneni verememiştir.

"Osmanlıcılık" ve "İslamcılık" akımının başarısızlığı İttihat ve Terakki yöneticilerinin ve doğal olarak Jön Türklerin kafalarında sr gibi sakladıkları "batıcılık" ve "Türkçüilük" politikasına geçiş konusuna yeşil ışık yakmıştır.

${ }^{13}$ Baskın Oran, Atatürk Milliyetçiliği, Resmi İdeoloji Dışı Bir İnceleme, İstanbul, 1990, s. $38-40$. 
İttihat ve Terakki'den çok önce var olan "Türkçülük", siyasi arenaya bu parti tarafından getirilmiştir ancak bu düşünceyle ilgili olarak -imparatorluğun temelinde sarsıntı oluşturur mu?- şeklinde çekinceler de vardır. Bu konuda ikinci bir çekince de "Türk" kelimesinin imparatorlukta o güne kadar sağlıklı bir şekilde kullanılmamasından kaynaklanmaktadır. Bazı çevrelerde de olsa "Türk"; "kaba, anlayışsız, zalim, cahil ve etrak-1 bi idrak" gibi tanımlarla açıklanmaktaydı. Öyleyse her şeyden önce bunun böyle olmadığı halka anlatılmalı ve ulusal bir bilinç oluşturul malıydı.

Jön Türklerin "Türkçülük" politikasını milliyetçilik eksenine oturtmasında iç dinamiklerden çok özcllikle Rusya Türklerinin çahışmaları etkili olmuştur. ${ }^{14} \mathrm{Bu}$ Politikanın şekillenmesinde Rus Türkleri etkili olduğu için "Türkçülük", "Turancılık" politikasına yönel mekte gecikmemiştir.

İttihat ve Terakki Müslüman Türkleri azınlıkların yerine egemen kılmak ve halkı tarımdan sanayi ve ticarete yönlendirmek için "Milli İktisat" politikası izlemiştir. Yerli girişimcileri yabancr şirketlere karşı korumak için 1913 yılında Teşvik-i Sanayi Kanunu'nu çıkarmış, Türklere parasız fabrika arsası ve makine, ham ve yarı işlenmiş mallar için gümrük bağışıklı̆̆ı săğ|amış, vergileri takside băğlamıștır.

Savaş sırasında Osmanlı Bankası zorluklar çıkardığı için, onun yerine ulusal bir bankanın kurulmasını gerçekleştirmiş ve 11 Mart 1917'de "İtibar-1 Milli Bankası" adıyla çalışmaya başlayan bu banka bütün işlemler.ini "Türkçe" yapmiștır. 15

İttihat ve Terakki ulusal sanayinin oluşması için çalışnıs yabancı ve azınlık şirketlerine karşı Anadolu Milli Mahsulat ve Ekmekçiler Cemiyeti gibi yerli kuruluşları desteklemiştir. İttihat ve Terakki'nin bu desteği sonucunda zengin bir yerli sinıf oluşturulmuştur. Böylece yerli girișimciler "ulusal kapitalizmi" öğrenmiştir. İttihat ve Terakki'nin bu gayreti azınlıklara da bir deneğim kazandırmıs ve Türkleri paravan veya orlak yaparak yollarında yürümeğe devam etmişlerdir. ${ }^{16}$

İttilat ve Terakki bazı çalışınalarıyla hem ulusallaşınaya hem de laikliğe gcçişe hizmet etmiştir ki Kuran-1 Kerim'in Türkçe'ye çevrilmesi ve hutbelerin Türkçe okunması bu çălş̧malardandı:.

İttihat ve Terakki'nin 1908 yllındaki parti programında: "Devletin resmi dili Türkçe'dir, her çeşit haberleşme ve yazışma Türkçe yapılacaktır" şeklinde bir madde vardır.

Ulusallaşma konusunda sadece programına maddeler yazmakla kalmayan İttihat ve Terakki, "Türkçülük" konusunda çok önemli görevler üstlenecek olan

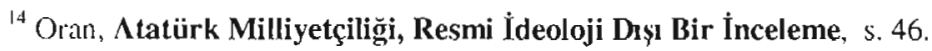

${ }^{15}$ Tevfik Çavdar, Türkiye'nin Demokrasi Tarihi 1839-1950, İstanbul, 1995, s.137.

Itr Oran, Atatïrk Milliyetçiliği, Resmi İdeoloji Dışı Bir İnceleme, s.50.
} 
Milli Talim ve Terbiye Cemiyeti ve Türk Ocakları gibi kuruluşları da faaliyete geçirerck Ulusal -devlet bilincinin oluşumunda önemli adımlar atmıştır.

İttihalt ve Terakki içerisinde "Türkçü̈" düşüncelerin şekillenmesinde görev alan Ziya Gökalp, Atatürk döneminde de bu etkinliğini sürdürmüştür.

Meşrutiyet döneminde Osmanl, yönetimi yasal düzenlemelerle eşitlik sağlamaya çalışırken Avrupalı devletler ve onların kışkırtıp desıeklediği Osmanlı "Tebaası" gayrimüslimler memnun görünmemenin çabasını veriyordu.

Meşrutiyet döneminin ilginç bir sahnesi şöyledir: "Günler geçiyor, Istanbul'da meşrutiyet lehinde gösteriler devam ediyordu. ...bizim hocalarımızla Rum ve Ermeni rahipleri, Musevi hahamlart arabalarda yanyana oturarak binlerce halkın "Yasassm Hürriyet, Kahrolsun istibdat" arasıra da "Padişahım çok yasa" avazelerile Beyoğlu ve Istanbul'un büyük caddelerinde dolastlrlliyor, Osmanll toplumunda din ve mezhep farkının kalmadığına dair hocalar, rahipler, papazlar tarafindan yer yer nutuklar veriliyor, karşlastnca hepsi birbirile kucaklasilyor, öpüşüyor, Messrutiyet idaresinin ilanıla çeşitli unsurlar arasındaki ayrllıkların tamamen kalkıı̆̆ gösterilmek isteniyordu.

Islam, Rum, Ermeni ve Musevilerden mürekkep kalabalik sehirde her sinif halktan aralartnda siviller ve zabitler bulunduğu halde rehberlik ederek, Rum, Emeni patrikhanelerine gidiliyor, Musevilerin sinagoglart ziyaret ediliyor, camilerin önünde toplanllyor ve biutiin bu tezahürat hocalarm, rahiplerin hitabelerile ilan ediliyordu. ... Osmanlı vatanunda el birliği ile çalışabilinesi milletin selameti ve ilerlemesini temin için mani kalmadı̆ı̆ ayn vatanın aynı hukuka malik vatandaşlarl olduğu söyleniyor, bu fikre sadık kalmacağına yemin ediliyordu. Bu nümayis ve hareketler şüphesiz ki belli mihraklardan, belli kaynaklardan tertip ediliyordu.

... "zananl gelmisti" işaretile birbiriyle kucaklaşan bu insanlart ayrt kutuplara. ayrı kamplara bölmesinin şiddete ve zaman zaman kana dayanan ac. manzaralarina da sathit olacaktk". 17

1914 yılındà başlayan I. Dünya Savaşı bu bölünmenin adeta doruk nokıasııı yaşattı. Çünkü; büyük devletlerin kendi menfaatleri için kullandıkları Ermeniler, Osmanlı ordusunu arkadan vurmaya başladı. Ermenilerin bu davranışı Osmanlı Imparalorluğu'nu tedbir almaya yöneltti. Bu tedbir; kargaşa yaratan Ermenilerin iç kesimlere gönderilmesini gerçekleştirmek amacına yönelikti. Bu uygulama "Tehcir Kanunu" olarak tarihte yerini aldl. 18

${ }^{19}$ Cemal Kutay, Osmanlıdan Cumhuriyete, Yüzyılımuzda Bir İnsanımı, Hüseyin Rauf Orbay (1881-1964), Istanbul, 1992, s. 24-25.

${ }^{18} \mathrm{Bu}$ yasă savaş sonrasında ve şimdilerde kasıtlı olarak bir katliam olarak değerlendirildi. Bugün de Avrupa Birliği'ne girme mücadelesi veren Türkiye'yc bunu kabul etmesi yönünde baskı uygulanmaktadır. 
Tehcir Kanunu Osmanlı İmparatorluğu'nun son dönemlerine damgasını basan İttihat ve Terakki tarafından çıkarılmıştır. Fakat İttihat ve Terakki' nin Anadolu'da yaşayan gayrimüslim unsurlara karşı katliam yapma yaklaşımı söz konusu değildir. Çünkü; İttihat ve Terakki Cemiyeti'ne kimlerin kabul edileceği tartışılırken " gïvenilecek her Osmanlı'nın alınması" fi fikri kabul edilmiştir. Dolayısıyla İttihat ve Terakki içerisinde farklı grupları da görmek mümkündür. Bu çerçeveden bakıldığında elbette ki karşılıklı öldürmeler vardır fakat bu bir katliam değildir.

Tehcir uygulaması Anadolu'da yaşayan gayrimüslim sayısını elbette ki azaltmıştır. Yine bu nedenlerle savaş döneminde ve savaş sonrasında gerçekleşen göçler de bu azalmada rol oynamıştır.

Aynı nedenler bir taraftan da Anadolu'daki Türk nüfusu arttırmıștır. Özellikle Balkan topraklarının kaybı ve bu topraklarda kurulan yeni devletlerin buralarda yaşayan Türklere karşı olumsuz, tavrı, Türklerin büyük kitleler halinde Anadolu'ya gelmesine yol açacaktır. Anadolu'daki Türk nüfusun artmasında Isozan'da 30 Ocak 1923 tarihinde imzalanan, "Yunan ve Türk Halklarının Mübadelesine İlişkin Söz.leşme ve Protokol"20 çerçevesinde gerçekleşen mübadele de etkili olmuştur.

Anadolu'da gayrimüslim nüfusun azalması öte taraftan Türk nüfusun artması sosyal yapıda, düşüncede, kültürde ve tabii ki siyasal yaşamda bir değişim dönemini de getirecektir.

Osmanlı İmparatorluğu'nun farklı din vc kökene mensup tebaasını (azınlık) asimilasyona tabi tutmayıp onların gerek birbirlerine ve gerekse toplumun diğer iiyelerine zarar vermeden yaşayabilmelerini sağlamış olması, özellikle devletin iç huzuru ve yöneticilerin inançlarının yerine getirilmesi bakımından elbette ki önemli bir durumdur. Ancak imparatorluğun bu anlayışı ve uygulaması uzun vadede değerlendirildiğinde olumsuz bazı sonuçlar ortaya çıkmaktadır. Çünkü dış dünyadaki gelişmelerin de etkisiyle imparatorlukta milliyetçilik fikirleri fillizlenme sürecine girmiştir. Bu konudaki en dikkat çekici nokta ise; ayrılıkçı düşünce ve - eylemlerin bu gruplar arasinda yeşermiş olmasıdır.

Milliyetçilik fikri ile Fransıı İhtilali arasında nasıl bir ilişki varsa, Osmanlı Imparatorluğu'nda gelişen milliyeççilik fikriyle ibadethaneler arasında da öyle bir ilişki vardır. ${ }^{2 l}$ İki olay arasındaki benzerlik kabaca şöyle değerlendirilebilir:

\footnotetext{
${ }^{19}$ Mehmet Kabasakal, Türkiye'de Siyasal Parti Örgütlenmesi 1908-1960, İstanbul, 1991, s. 25.

${ }^{201}$ Meray, Lozan Barış Konferansı, Tutanaklar- Belgeler, II/II, s. 82-87; Cemil Bilsel, Lozan, II. İstanbul, 1998, s.293-295; Kara, Tabiiyetten Vatandaşlığa Geçiş Sürecinde Türkiye'de Aznnlıklar, s. 206-213.

${ }^{21}$ İbadethane yerine "kilise" sözünü kullanmamaktaki kasıt, bu yargıyı belli bir dönemle kısıth tutmamak düşüncesinden kaynaklanmaktadır. Hatırlanmalıdır ki her dinî kurum, kendine
} 
Milliyetçilik, Fransız İhtilali'nin bir sonucuyken Osmanlı İmparatorluğu'nda ortaya çıkan milliyetçilik, daha çok ibadethanelerin çalışma ve tahriklerinin bir sonucudur.

Din ve din̂̂ kurumların ulusalcı yaklaşımları (Osmanlı İmparatorluğu'nun son dönemleri için kilise ifadesi kullanılabilir.) ve ardından gerçekleşen ulusal devletler, kendilerinin de oluşumunda önemli bir rol üstlenen bu kurumları kontrol altında tutma ihtiyacı duymușlardır.

Ulusal devletlerin bu yaklaşımı sadece kendisine zarar veren karşı dinlerin kurumlarma yönelik bir Lavır değildir. Çünkü çoğu zaman "ulusal" olma fikrine karşı çıkan dinler de başlı başına ulusal devlet için bir tehlike oluşturmaktadır.

Bu değerlendirme ışı̆̆ında Türkiye Cumhuriyeti ele alındı̆̆ında şunlar söylenebilir: Türkiye Cumhuriyeti; 1299'da kurulan ve 1922 yılında Saltanatın kaldırılmasıla tarihe mal olan bir imparatorlugun, yani 623 yıl ömürlü Osmanlı İmparatorlığu'nun tek mirasçısıdır. Türkiye Cumhuriyeti, bayrağı Osmanlı İmparatorluğu'ndan devralmış ve daha da ileriye götürmeye azmetmiştir. Ancak bayrağı ileriye götürebilmenin ön koşulu vardır. Bu koşul tek kelimeyle çağın bekJentilerine ayak uydurmaktır.

\section{Lozan ve Yeni Bir Dönem}

Çă̆ın bir koşulu ulusal devlet olmaktır. Hatırlanacaktır ki I. Dünya Savaşı

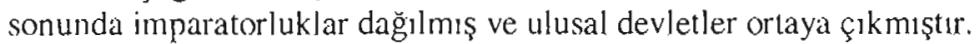

Birçok ulusu bünyesinde barındıran Osmanlı İmparatorluğu da yıkılmıştır. Elde kalan toprak Misak-1 Milli ile çizilen, adına Türk Yurdu denilen Anadolu'dur. Anadolu'nun nüfus yapısı çoğunluk olarak ırken Türk, dinen Müslüman'dır.

Savaş sonrası düzenlemeler için toplanılan yer Isviçre'nin Lozan kenti olacaktır. Çă̆ın gereklerine ayak uydurma gayreti burada kendisini hemen belli edecektir. Çünkü: görüişmelere gitmeden Saltanat I Kasım 1922'de kaldırılmıştır. Saltanatın kaldırılmasının görünen gerekçesi; Lozan görüşmelerine gitmek isteyen İstanbul Hükümeti'nin,, ${ }^{22}$ ve onu çağıran Batılı Devletlerin ${ }^{2.3}$ oyununu bozmaktır.

Milli Müicadele'nin önder kadrosunun saltanat ve hilafet hakkındaki düşiinceleri hatırlanacak olursa ${ }^{24}$ bunun dışında bir gerekçe sunmanın zorluğu kendiliğinden ortayă çıkacaktır. Öyleyse saltanatın kaldırılması aynı zamanda imparatorluk düşünce yapısının da değişmesi demektir. Bu çerçevede bakıldı ğında ulusçułŭgun ön plana çıktığı söylencbilir. Nitekim diğer kurumlardaki millileşme

inananları çeşitli dönemlerde çeşitli gorisşlere ve çeşitli eylemlere sürllkleyebilmiştir ve sïrüklemektedir.

22 Mustafa Kemal Atatilirk, Nutuk-Söylev, II, Ankara, 1987, s. 915-917.

2.3 Atatiurk, Nutuk-Söylev, II, s. 9। I; Ergiin Aybars, Tür-kiye Cumhuriyeti Tarihi, I, Ankara, 1994, s. 351 .

${ }^{24}$ Alatürk, Nutuk-Söylev, II, s. 913-915. 
ifadeleri; Kuva-yı Milliye, İrade-i Milliye, Hakimiyet-i Milliye, Misak-1 Milli, Türkiye Büyük Millet Meclisi ve daha sonraları Milli Müdafaa, Milli Eğitim gibi kavramların yaygınlaşması, ulusalcılık fikrinin güçlendiği iddiasını pekiştirmektedir.

Lozan Barış görüşmelerinde yeni devletin olaylara yaklaşımı sàvaş dönemindeki açıklamaları ile aynı paraleldedir. Yani belirleyici unsur Türklük ve Müslümanlıktır.

Yalnız, yeni devletin Türklük yaklaşımı etnik kökene dayanmamaktadır; çünkü Türk Devleti'nin kurtarılmasında ve kurulmasında bazı gayrimüslimlerin dahi payı vard. ${ }^{25}$ Bunun içindir ki yeni devletin kurucusu da bu yönde sözler sarf etmiştir. Mustafa Kemal Atatürk'ün: "Türkiye Cumhuriyetini kuran Türkiye halkına Türk Milleti denir" sözzü "Türk vatandaşlık Kanunu"nda dà yansımasını bulmuştur. ${ }^{27}$

Türk Devleti imparatorluk döneminin tüm uygulama ve bakış açılarından kurtulına azmindeydi. İlk bakışta pek dikkat çekmeyen, fakat derin anlamlar içeren yeni bir uygulama da Ankara'nın başkent seçilmesiydi.

Malatya Mebusu İsmet Paşa ve on dört arkadaşının 9 Ekim 1923'te verdiği kanun teklifi mecliste görüşülmüş ve çoğunluk tarafindan 13 Ekim 1923'te kabul edilmiştir. ${ }^{28}$ Konuyla ilgili görüşmeler devam ederken Gelibolu Mebusu Celal Nuri Bey şu sözleri söylemiştir: “.... Biz. Ankara'yı merkez ittihaz etmekle başl bașına manayl miifit bir program ittihaz ediyoruz Istanbul beynelmilel, fevkalmilel Osmanll Hiikiimeti'nin makarrydi. Ankara milli bir devletin, bir devlet-i hürrenin makarr olmak ïzere ayrica bir manay müfittir. Binaenaleyh biz. Ankara'da yeni devletimizi, yeni hükü̈metimizi, yeni teskilatımızı kuracă̆ız ....,29

Yine ayni konu hakkında Aksaray Mebusu Besim Atalay Bey'in şu sözleri de ilginç kabul edilebilir: "....sonra bugünkü Istanbul'un, Feridleri ve arkadaşlarm yetistiren zihniyeti kısmen devam ettikçe bizim oraya gitmemizde. zannederim mahzurlar vardır. Binaenaleyh burası tamamen dezenfekte edilmedikçe oraya gitmek hazin ve ihtiyata muvafik değildir arkadaslar. Ve biz burada tozlar içersinde yaşariz...."30

25 Başbakanlık Cumhuriyet Arşivi ( BCA ), 030 ( 25.12.1927) $1801 / 027 \quad 70$ 14; $030(25.12 .1927) 1801 / 912635$.

26) Utkan Kocatürk. Atatürk, Ankara, 1987, s. 127.

${ }^{27}$ Düstur, III. Tertip,IX, s. 994- 995, No: 207. (23 Mayıs 1928).

28 Türkiye Büyük Millet Meclisi Zabıt Ceridesi (TBMM. ZC.), LI. i:tihap Devresi, Birinci İçtima Senesi, II, Ankara, s. 665-670.

29) TBMM. ZC., Il/I, s. 669 .

${ }^{30)}$ TBMM. ZC., II/I s. 670 . 
Ankara'nın başkent seçilmesi elbette ki çok farklı anlamlar taşıyordu. Nitekim bir Batılının konuya yaklaşımı şöyledir: “....Karar, geçmisten yeni bir uzaklasma-Saltanatın kaldirlmasinın mantiki bir sonucu-anlamina geliyordu. Padişăh gitmişti; imparatorluk şehri onu deviren devrimciler için hâlâ elverişli bir yer değildi. Bes yüz yala yakın bir süre Istanbul bir Islam Imparatorluğunun baskenti olmustu; muhtesem bir geçmişin solgun hayaletleri sarayın ve Babuali'nin koridorları arasinda hala uğursuzca çırpınıp duruyorlardı. Bir yandan camileri ve saraylart, kutsal yerleri ve saray maiyetiyle Türk Istanbul; öte yanda müteahhitlerin ve kompradorlartn kozmopolit tüccar topluluğuyla tath su Frenklerinin dis mahallesi Beyoğlu; bunlar, gerçekte ve Türk halkının zihninde, Mustafa Kemal'in kurmak istediği yeni Türkiye'ye bir merkez sağlayamayacak kadar geçmisle yakın. ortaklık içindeydi. Böylece, meydana gelmekte olan değisiklikleri sembollestiren ve iyice belirten yeni bir baskent seçildi. Yeni devlet bir hanedan, imparatorluk veya din üzerine değil, Türk ulusuna dayaniyordu ve baskenti Türk anayurdunun kalbinde idi.". 31

Saltanatın káldırılması ve Ankara'nın başkent seçilmesinde görülen bu ulusal adım hilafettin kaldırılmasıyla daha da pekiștirilecektir.

Çünkü dinî bir kurum olan hilafettin varlığı, ulusal devlete geçişin önünde bir engeldi. Burada din-hilafet ikilisini birbirinden ayırmak gerekir. Elbette ki ulusal devlet için din terk edilmeyecekti. Fakat hilafet; tüm Müslümanları bir çatı altında tutmak ya da en azından bunun mücadelesini vermek durumunda olduğu için ulusal devlet anlayışıyla örtïş̧memekteydi. Ancak burada farklı bir konu gündeme gelmektedir: Neden hilafet kaldırılarak ulusalcılık alanında bir adım dalıa atıldı da Patrikhanc ya da Hahamhane konusunda ayn sonuca varılmadı veya varılamadı?

Patrikhanenin kaldırılması konusunda Türkiye Lozan'da ırareı bir tavır sergilemiş olmasına rağmen, bu kurum hakkında yine eskisi gibi cemaatin din ve dünya işlerine bakması vo hattá ekümenlik denilen evrensellik ilkesinin devaını konusunda Batılı devletlerin yoğun istekleriyle karşılaşmıştır. ${ }^{32}$ Batılıların bu yoğun istekleri karşısında Patrikhanenin sadece din işleri ile uğraşması şartıyla varhı̆ı Lozan'da kabul edildi. Lozan sonrası dönemde Cumburiyet hükümetleri, Patrikhanenin tăınan statü dışına çıkmaması için bu kurumu kontrol altında tutmalyı ihmal etmedi. Görünen o ki, bu kontrolui de iyi bir şekilde gerçekleştirdi. Ömeğin; 1926 yilında İskenderiye veya Aynaroz'da gerçekleştirilmek istenen konferansa katılmak isteyen patrikhancye izin verilmedi. ${ }^{33}$ Bu konuda tarihsel gelişim doğrultusunda şunlar söylenebilir; Lozan'da ekümenlikten arınan ve sadece Türkiye'deki Rum Ortodoksların din işleriyle uğraşmassına izin verilen bir

${ }^{31}$ Bernard Lewis, Modern Türkiye'nin Doğuşu, ( Çev: Metin Kurath ), Arkara. 1984, s. 260.

32 Seha L. Meray, Lozan Barıs Konferansı, Tutanaklar-Belgeler, I/II, İstanbul, 2001, s. 193-194 ve $221-222$

3 BCA., $030(15.09 .1926) 10972427$. 
patrikhane kabul edilmiştir. Dirayetli Türk hükümetleri bu sınırın dışına çıkmak isteyen Patrikhaneyi engelleme kararlılığını göstermiştir. Ancak gelişen diş olaylar ve Türkiye'nin takip ettiği dış siyaset ve denge politikaları nedeniyle zaman zaman Lozan statüsü çiğnenmiştir ve çiğnenmektedir. Bu gelişmeler Hilafet-Patrikhane karşılaşurması şcklinde ele alındı ğında şöyle bir değerlendirme yapılabilir: Her iki kurumun bu siyasi alanlara müdahale girişimi, Laikliğe aykırıdır. Ancak Patrikhanenin bu távrı resmi ideoloji yaklaşımına göre en azından Cumhuriyeti ve laik sistemi yıkmaya yönelik bir tavır olarak değerlendirilmemekte, hilafet ise laikliğe geçiş ve ulusal devlet anlayışına bir cngel olarak görülmektedir. Fakat daha da açık bir ifade kullanılacak olursa söylenecek söz şu olabilir: Patrikhane siyasi destekli olmasına rağmen, hilafet gerçek anlamda bir destekten ve istekten mahrumdu.

Yeni Türk Devleti'nin "ulusal" olma yolundaki önemli çalışmalarından birisi de dil alanminda olmuştur.

Gün]ük hayatın her alanında yer tutan dil, bilimsel çalışmalanı ortaya konmasında da bu önemini korur. Böylesine büyük bir öneme sahip olan dil, herkesin anlayabileceği ve herkesin kendisini rahatça anlatabileceği özellikte olmalıdır. Çünküi dil, anlaşılabildiği oranda kalıcı olabilir. Dil, aynı zamanda ulus devlet olmanın ve milli kültürü koruma oranının bir göstergesidir. Bunun içindir ki ulusal devletin kurucusu Mustafa Kemal Atatürk, dil konusunda da gereken duyarlılı̆̆ göstermiş ve Türkçe'yi konuşulan ve anlaşılan bir dil yapmanın mücadelesini vermiştir. Ulusal önder konuyla ilgili olarak düşüncesini şu sözlerle ifade etmiştir: "Milli his ile dil arasındaki bağ çok kuvvetlidir. Dilin milli ve zengin olması milli hissin gelişmesinde başlıca etkendir. Türk dili, dillerin en zenginlerindendir; yeter ki bu dil, suurla işlensin.

Ülkesini, yïksek bağımsızlı̆̆ını korumasını bilen Türk Milleti, dilini de yabance diller boyunduruğundan kurtarmalıdır." ${ }^{34}$ Ulusal önderin bu yaklaşımı diger alanlarda da olduğu gibi sözle kalmamış ve derhal uygulamaya konmuştur.

Türk dilinin yaygınlaştırılması yönündeki en önemli çalışmalardan birisi "Vatandaş Türkçe Konuş" şeklinde sloganlaşan kampanyadır. "Vatandaş Türkçe Konuş" kampanyası 13 Ocak 1928 tarihinde Dar-ül Fünun Hukuk FaküItesi Talebe Cemiyeti’nin yıllık kongresinde ele alınan ve azınlıkların Türkçe konuşmalarını sağlamayı hedef alan bir uygulamadır. ${ }^{35}$

Ulusal devlet olma yolunda "dil"in önemini fark eden ve aslen bir Musevi olan Türk vatandaşı Avram Galanti Akşam gazetesinde "Türkleşmek Yolu" işminde bir yazı yazmış ve şöyle demiştir: "....Balada, bir milliyette vahdet husule getirmesine muktezi umumi avamilin, din, mesken, örf-adet ve ba-husus lisandan ibaret olduğunu zikrettim... Türkiye'de yasayan ve dilleri Türk dilinden gayri olan

\footnotetext{
${ }^{34}$ Kocatürk, Atatürk, s. 164.

${ }^{35}$ Kara, Tabiiyetten Vatandaşlığa Geçiş Sürecinde Türkiye'de Aznlıklar, s. 166
} 
anastr, bu içtimai kanundan hariç kalamaz. Bunlar kavlen, ismen ve resmen Türk olabilirler; lakin ruhen, fikren, kalben Türk olamazlar. Çünkü Türklü̈̌̈i hissedentezler. Çünkü Türklügü hissettirecek avamilden biri olan Türkçe'den mahruindurlar...."36

Cumhuriyet hükümetlerinin ve Türkiye Cumhuriyeti vatandaşı Musevi kökenli Avram Galanti’nin görüşleri örtüşmekteydi. Cumburiyet döneminde Türkçe'nin canlanması, işlerlik kazanması için çaba sarf edildi. Örneğin, 1930'lu yıllarda okul kitaplarında, resmi yazışmalarda, günlük gazetelerde Türkçe kelimeler kullanılmaya başlandı... Artık; muselles, üçgen; müselles mütesavi'l adla, eşkenar úçgen; zû erbaat-üt adla yerine dörtgen denilmeye başlanmıştı. ${ }^{37}$

Yil 1938 olmuştur. Acaba toplumsal anlamda değişen ne vardır? Peyami Safa Cumhuriyet gazetesindc çıkan yazısında durumu şöyle anlatır: "....Artık, ekalliyetlerin umumi yerlerde Türkçe konuşmalan lâzun geldiģini ispat etmek için, en aşağl on beş seneden beri ve belki de, en aşağı on beş bin defa yazlan delillerden aym bir sey söylemeye imkan yoktur. Artık. "Sabahleyin günes doğar" yahut "elinizdeki semsiyeyi brakırsaniz yere diuser" nevinden bedahetler arasina giren bu basit hakikatin ispata ve tahlile muhtaş hiçbir şüpheli tarafi kalmamuştu: Fakat, ekalliyetler arasinda, bazı dilleri kuruyasicaların umumi yerlerde Türkçe konuşmanaktaki inatlarını hâlâ kıramamıs olduğumuz için aynı bedahetleri on beș bin birinci defa tekrarlamak gerekiyor...."38

Peyami Safa 1938'de Türkçe'nin yeterince konuşulmadığını bu sözlerle aktarıyordu. Acaba 2004'lü yıllarda Türkçe ne kadar konuşuluyor ve Türkçe'nin zenginleşmesi için neler yapılıyor? Türkiye'de Türkçe ne kadar doğru kullanılıyor? Anadolu'da küçük kasabalarda dahi birçok iş yeri Türkçe olmayan isimler taşıyor. Basın yayın organlarının bir çoğu ve özellikle televizyon kanalları Türkçe kelime yerine İngilizce karşılığını kullanmayı tercih cdiyor.

Ulusal önder dil konusunda da duyarlı davranarak Türkçe'yi zenginleştirmenin mücadelesini vermiştir. Bu yöndeki çalışmalardan birisi 1934 yılında kabul edilen Soyad Kanunu'dur. $^{30} \mathrm{Bu}$ kanun sosyal hayatta isim benzerliğinden kaynaklanan bazı sıkıntıları gidermeyi hedeflediği gibi, Tüıkçe' nin zenginleşmesini de sağlamıştır. Çünkü kabul cdilccek olan soyadların Türkçe olması kanunda belintilmişti. Dolayısıyla az kullanılan veya unutulan Türkçe kelimeler cle bu şekilde yeniden dile kazandırılmak isten mekteydi.

3. Avram Galanti, "Türkleşmek Yolu", Atatürk Devri Fikir Hayatı, II, (Haz: Mehmet Kaptan, Inci Engünün, Zeynep Kervan, Necati Birinci, Abdullah Uçman), Ankarn, 1992, s. 546-548.

${ }^{37}$ Zeynep Korkmaz, Atatïrk ve Türk Dili, Belgeler. Ankara, 1992, s. 414-418.

${ }^{36}$ Peyami Sala, "Dil Fethi", Cumhuriyet, 30 Tcmmuz 1938.

31) 21 Haziran 1934. TBMM. ZC., IV/ XXIII, s. 254. 
Sosyal hayatı ve dili etkileyen en önemli alanlardan birisi de hiç şüphesiz ki din ve bununla ilgili ibadettir.Tarih, İslamiyet'in kabulünden sonra Türkçe'nin önemli bir ölçüde bu dinin i ade kaynăğ olan Arapça'nın etkisi altına girdiğini göstermiştir. Hatta bu etki, o kadar ileri gitmiştir ki bir dönem Arapça resmi dil konumuna bile gelmiştir. ${ }^{40}$ Dine değil; fakat ibadetin Arapça olarak yapılmasına karşı çıkan ulusal önder, bu konuda da bir takım tedbirler alma yoluna gitmiştir. Bu yollardan birisi "Ezan"ın Türkçe okunmasıdır. 1932 yılında başlatılan bu uygulamayla aynı zamanda Kuran-ı Kerim'in Türkçe tercümesinin okunmasına da gidilmişti.

Kuran-ı Kerim'in Türkçe tercümesi ilk defa İstanbul Yerebatan Camî̂'nde Hafiz Yasar (Okur) taralindan okunmuştur.

3 Şubal 1932 tarihinde Ayasofya Camị̂̂nde Türkçe Kuran-ı Kerim okunmuştur.

5 Şubat 1932 tarihinde İstanbul Süleymaniye Camî̀'nde ilk kcz Türkçe hutbe okun muştur.

Atatürk; ezan, tekbir, sala ve hutbe gibi ibadetin önemli alanlarında Türkçe'yi ön plana çıkarmıştır. Atatürk'ün bu tavrını: "Türkler dinlerinin ne' olduğunu bilniyorlar. Bunun için Kur'an Tïrkş' olmaludr." "4l şeklinde açıklayanlara rastlanmaktadır. Bu her ne kadar kabul edilebilir bir yaklaşım isc; Atatürk'ün bu çalışmayla Türkẹe' yi geliştirme, baskıdan kurtarma isteğinde olduğu da bir o kadar kabul edilebilir yaklaşımdır. Çüinkü, dil ve tarih alanındaki millileşme çabaları, yani Türk Tarihi Tetkik Cemiyeti vc Türk Dili Tetkik Cemiyeti'nis kuruluşu bunı doğrulamaktadır.

Selçuklu ya da Osmanlı İmparatoriuğu döneminde Arap̧̧a'nın yaygın olarak kullanılmasını doğal karşılayanlar bulunmaktadır. Bu fikri savunanlar: “.... Bir yerde bu doğaldlr. Cü̈nkü, doğuda Arapça, batula Latince'ninkine paralel bilim dili olarak kendini kabul ettirmisti. Bu durumda Türk bilim adam da eserini genellikle Arap̧̧a Tü̈k edebiyatçısı Farş̧ı'yı kullanıyordu...."42 demektedir.

4) Aydın Tăneri, Türk Kavramı'nın Gelişmesi "Ne Mutlu Türküm Diyene”, Ankara, 1983, s. 37.

41 Ahmet Gürtaş, Atatürk ve Din Eğitimi, Ankara, 1981, s. 41.

42 Taneri, Türk Kavramı'nun Gelişmesi, s. 37.

Oysa Karamanoğlu Mchmet Bey, 'Türkçe'yi resmi dil yapıyor ve tavrını da şu anlamlı sözlerle ortaya koyuyordu: "Simden girii his kimesne kapuda ve divanda ve necalis" ve" seyranda Türki dilinden gayri dil söylemeye." Bu sözden anlaşılacağ1 gibi Karànanoğlu Mehmel Bey, sosyal alanin tiimínil bu uygulamaya dahil etmiştir. Görilldüğä üzre Arapça sadcce bilim alanında egemen değildi.

Bugün Türkçe yinc diğer dillerin özellikle İngilizce'nin etkisi altında varlığını sürdürmeje devam etmcktedir. Ne ilginçtir ki sözüm ona bazı aydınlar, Türkçe'yi bilim dili olmaktan uzak görmektedirler. Bir dil kullanıldıkça zenginleşir. Türkçe de bu anlamda 
Ulusallaşma çabası içerisinde Türk Tarih Tezi de önemli bir yer tutmaktadır. Bu tez; bütün dünyaya uygarlığın Orta Asya'da yaşayan Türkler larafindan göıürüldü̈ğ̈nü, Türklerin mimarlıkıa Kübizmin, resimde sürrealizmin kurucusu olduğunu, ateşi, ekmeğgi, evlilik kurumunu, tarmm, madenciliğgi, geometriği, hayvan ehlileştimeği dïnya uygarlığına Türklerin tanıı̆ğm dile getirmekteycli. ${ }^{43}$ Her ne kadar tartışılan ve bir müddet sonra önemini yitiren bir tez olsa da, hor görüilmeye çalışılan Türklere moral güiç veren önemli bir çaba olarak kabul edilebilir.

Yukarıdaki ifadelerden de anlașlacağı gibi Milli Mücadele sonrasında ulus-devlet olma konusunda önemli çabalar sarf edilmiştir. Bu çabalar tesadüfi olmayıp belli bir düzen ve özen içerisinde sïrdürülmüștür. Ancak Atatürk’ten sonra iş başına gelenler aynı hassassiyeti göstermemiş, hatta bazen eskiye dönme konusunda girişimlerde bulınmuşlardır. Ulusal politika izlemek ve buna süreklilik kazaındırmak bir hükümet değil bir devlet politikası olmalıdır. İş başına gelen her hüküimet, ulusal politikada sık sık değişiklikler gerçekleştirecek olursá bu uygulamalara tabi olan ulus, ne yapacağını bilemez ve yozlaşmıs bir kültürün ortaya çıkması kaçınılmaz olur.

\begin{abstract}
ABSTRAC'T
Ottoman State had been transformed into the emperorship due to the successful administrators and the conquest which these administrators had taken into reality. This emperorship containing various races, religious, religious secl and of coursc languages, had behaved with quietly tolerance. The movement of "Nationalism" which French Revolution had made out, made weak the Ottoman Empire as the other emperorships. Because different groups which the empire contains, had also been influenced by the attractiveness of nationalist movement. Despite all these developments Turks, whom were the real founder, refused this movement for the attendance of empire. The Empire had begun to tace up to strokes as strong as the empire couldn't have succeeded. The nationalist idea had begun to improve among Turks by these strokes getting more intense. Turks had gotton to begin struggle for a new state at the lands remaining from The Empire. In history this struggle took
\end{abstract}

zenginleşmeyc yatkın bir dildir. Türkçe'nin bahtsıłı̆ğ bu dilin zenginliğinin farkında olan duyarlı bir aydınlar grubuna sahip olmamasındandır.

${ }^{43}$ Oran, Atatürk Milliyetçiliği, Resmi İdeoloji DL\$\$ Bir Ínceleme, s. 254-255. 
place as "The Turkish War of Independence". After a bloody guarrel a new state were founded. This state is Turkey and after declaring the republic its name were transformed into "Turkish Republic". Now, as the other states, it also would have been applied a national politics in this state.

Mustafa Kemal Atatürk, who is the founder of the state, realized newness in the direction of getting nationalistic tone. His works newer directed to racism. Because he appropriated all the people with the conjunction of citizenship and for all whom appropriating this conjuction he said "How happy is the person who says I am Turk." 